\title{
The Effects of Writing to Learn (WTL) on Academic Achievement and Attitude to Lesson in English Classes
}

\author{
Ayhan İncirci ${ }^{1, *}$, Ramazan Şükrü Parmaksiz ${ }^{2}$ \\ ${ }^{1}$ Faculty of Education, Duzce University, Turkey \\ ${ }^{2}$ Education Faculty, Bulent Ecevit University, Turkey
}

Copyright $(\mathcal{C} 2016$ by authors, all rights reserved. Authors agree that this article remains permanently open access under the terms of the Creative Commons Attribution License 4.0 International License.

\begin{abstract}
The aim of this study is to investigate the effects of applying the writing letter activity of writing to learn strategies on the English Language Academic Achievement and Attitude level of $11^{\text {th }}$ grade students. The research was carried out with 84 students (43 male, 41 female) at one of the state schools in Black Sea Region of Turkey. Mixed method was used in the research. A non-equivalent control group model which is one of the quasi-experimental methods was used in the quantitative part of the research. Simple Past Tense Achievement Test (SPTAT) developed by the researcher and Attitude to English Lesson Questionnaire (AELQ) developed by Erdem (2007) were used to obtain the quantitative data. Structured interview questions were asked to the six students chosen from the experimental groups using the maximum variety technique. At the end of the research, it is detected that using writing to learn strategies in English classes makes statistically significant difference for the benefit of experiment groups on the level of academic success and attitude to lesson.
\end{abstract}

Keywords Writing to Learn, Letter Writing Activity, Teaching English, Academic Achievement, Attitude

\section{Introduction}

It can be stated that; although the significance of writing activities is increasing day by day and the teachers think that these activities are important, writing activities are not used sufficiently, and some teachers fail to possess the skills and knowledge to apply these activities [1]. Whereas writing activities are the key components of critical thinking and efficient learning, these skills are not improved in students. Despite the fact that the teachers agree on the significance of writing activities, they fail to give these activities to the students within an efficient teaching method [2]. Teacher trainers define the writing activity as personal, individual, subjective, comprehensive and elaborate (integrated, mixed, blended) activity, and teacher candidates express that they find writing valuable for both themselves and the students they are to teach [3].

The "writing" skill, which takes place among the four basic skills (listening, speaking, reading, and writing) in foreign language teaching, is a skill that is significant yet difficult to teach. Because teaching writing is so important in Teaching English as a Second Language (TESL), it has become inevitable to carry out a study in this area. One of the writing activities used in education is, Writing To Learn (WTL). WTL activities are used in other fields of education such as Science and Maths teaching [4,5] but not used commonly in TESL [6]. WTL activities are different from other writing activities; WTL activities are included in the process part of the education instead of the output part. In simple words, these activities can be defined as designs where the learners explain how they perceive the scientific expressions and concepts and how they re-create those themselves, instead of a way of communication with the teacher [7]. They are based on concepts and learning [8]. The students can use WTL activities to express the subject they have learned with their own opinions through writing [9]. The students who are counselled about the application of WTL activities can complete their studies in a shorter time, and they can be successful [10]. Hohenshell and Hand [11] in the studies made with the mixed method, they have expressed that WTL could have a positive effect on learning, yet, experimental practices were needed more. They have carried out an experimental study to find out that the students who used the WTL activity were more successful. When the literature is reviewed there can be seen plenty of studies related to WTL activities in variety of fields in variety of formats such as thesis or articles [12-22]. Studies related to Teaching English as a Second Language using WTL activities are very rare. It can be stated that it is necessary to conduct an experimental study in order to investigate the effect of WTL activities in the students' success in learning a foreign language.

From birth to death human language learning has a natural system in order as listening, speaking, reading and writing. Writing is the climax of human's metacognition level in terms of learning language [23]. Writing is a challenging activity however WTL activities are different from and more 
challenging activity than regular writing activities. Moreover, it is mistaken for regular writing activities (LTW). As WTL is mistaken for the LTW letter writing activity, it will be beneficial to explain rationale. Stufflebeam describes four dimensions of the learning process. These are defined as the "context, input, process and product" respectively. It would be wrong to consider WTL as an "output" in the learning process. WTL takes place in the "process" stage. The basic purpose of this activity is to help the students materialize the immaterial information and concepts that are available in their cognitive world through writing. In this way, the student and the teacher can see the learning process materially, and they can determine any points that require intervention. The materialization here is made not to reveal out what the student has learned but to reveal out how he/she has learned that. Thus; the risks for the possibility of faults observed in the outputs produced can be minimized in the former dimension for the individuals who manage the learning process accurately.

Just like in any lesson it is also essential for foreign language education to have the students acquire a positive attitude towards the lesson. The methods and techniques utilized play a major role in this. When training the students not only to know the language but also to be able to use that for communication purposes, it is essential to utilize appropriate methods and techniques to help the students acquire a positive attitude towards the language, to love the language and to lay a strong infrastructure for the language [24]. WTL activity used for this purpose can be stated to be influential in having the students get strongly bound to the subject and become more successful than the others [25]. Furthermore; these activities can have effect in improving the relationship between the students and the teachers.

\subsection{Problem of the Study}

How do "Writing To Learn activities" affect academic achievement and the attitude of the students in TESL classes?

\subsection{Hypotheses}

1. The pre-test and post-test scores of the achievement test applied on the experimental and the control groups present a statistically significant difference in favour of the post test.

2. The post-test scores of the achievement test applied on the experimental and control groups present a statistically significant difference in favour of the experimental groups.

3. The pre-test and post-test scores of the lesson attitude test applied on the experimental and control groups present a statistically significant difference in favour of the post test.
4. The post-test scores of the lesson attitude test applied on the experimental and control groups present a statistically significant difference in favour of the experimental groups.

5. The students in the experimental group think that (WTL) have a positive effect on their academic success and their attitudes towards the lesson.

\section{Method}

Information about the research method, model, study group, data collection tools, and data analysis are given in this section.

\subsection{Design of the Study and Application Process}

Mixed method design was used in this study. The data obtained through the quantitative, and qualitative methods were viewed together in the research. In the qualitative method, one of the semi-experimental methods, that is, the "non-equalized control group model" was used. Three groups participated in the study in this group. Lots were drawn to divide these groups into experimental and control groups. In this respect, one of the groups was assigned as the control group and the other two groups were assigned as the experimental groups. Pre-tests (SPTAT, AELQ) were applied on all the three groups prior to the beginning of the study. Then, the researcher taught "Simple Past Tense" to all groups using the same method and technique. Whereas one of the Writing To Learn activities, that is, the letter writing activity was applied to the experimental groups, the control group was given the activities in course book as homework. Post-tests (SPTAT, AELQ) have been implemented once the activities were finished.

The subject was studied for seven weeks with the $11^{\text {th }}$ graders of the secondary school. First of all, the students in the experimental groups were informed about the writing to learn activity. Necessary instructions were given and the questions of the students were answered in an elaborate way. Here, the students were clearly and elaborately informed that the activity had to be in letter form and scientific, they were told whom to write to and about what to write, when to submit it, and how it would be assessed. The students performed the activity in the classroom under the guidance of the researcher at the first place. Then they did it at home as homework. The letters were assessed through a rubric prepared by the researcher. The rubric was handed out to the students prior to the activity, and necessary explanations were made. Feedback was given to whole class about the letters that were assessed. Every letter was written in unity with the previous subject. Thus; the students found the chance to materialize the structuring of knowledge. 
Table 1. Application Process

\begin{tabular}{ccc}
\hline Time & Experimental Group & Control Group \\
\hline $1^{\text {st }}$ Week & Application of Pre Tests & Teaching time expressions of Simple \\
& Past Tense \\
$2^{\text {nd }}$ Week & $\begin{array}{c}\text { Teaching time expressions of Simple Past Tense } \\
1 \text { st Writing Letter To Learn Activity }\end{array}$ \\
\cline { 2 - 3 } $3^{\text {rd }}$ Week & Teaching Condition Verb (be) & Teaching Condition Verb (be) \\
$4^{\text {th }}$ Week & Teaching Regular Verbs & Teaching Regular Verbs \\
$5^{\text {th }}$ Week & 2nd Writing Letter To Learn Activity & Regular Exercises \\
$6^{\text {th }}$ Week & Teaching Irregular Verbs & Teaching Irregular Verbs \\
$7^{\text {th }}$ Week & Teaching Irregular Verbs & Teaching Irregular Verbs \\
$8^{\text {th }}$ Week & $3^{\text {rd }}$ Writing Letter To Learn Activity & Regular Exercises \\
$9^{\text {th }}$ Week & Application of Post Tests & \\
\hline
\end{tabular}

The activity was not the regular letter writing activity performed in English lessons. The regular writing activity includes any letter written in daily life and is applied to help the students practice what they have learned. For example; when teaching the simple past tense if the students are asked to write about what they did last weekend to their friends in English, this is a traditional letter technique. It takes place in the final "output" part of the learning process, and it can be called as Learning To Write (LTW) as the objective here is to write using the simple past tense. Here, "what" the student has learned is being assessed. On the other hand; the activity in question takes place in the "process" part, and the student's learning process is still continuing. The objective to write the letter here is to learn the subject that has been taught (WTL). When learning the subject, the students try to materialize the processes they have cognitively utilized when learning the subject. The students are asked to write how they have learned, and the students write these letters in their native tongue. The students are expected to reflect the subject materially as they have learned it through their cognitive schemes and concepts by illustrating with pictures, examples, and graphics. "how" the student has learned, is significant here. The purpose is to observe the process, guide the student properly and to help the student acquire a cognitive behavior.

The same teacher lectured all the groups throughout the activity. Following the explanations about the writing to learning activity, the letters written by the experimental group students addressing to the secondary school $10^{\text {th }}$ graders were delivered to the researcher. In the meantime; the control group students were asked to do all the Simple Past Tense activities available in the course book and workbook. The process steps are shown in Table 1.

The experimental group students were interviewed in the qualitative part of the research. One of the purposeful sampling methods, the maximum variety method was utilized in the election of the students to be interviewed. The objective in the maximum variety sampling is making use of varieties to reveal out the commonalities and similarities among the situations that create variety in the universe [26]. The results of the achievement test and the attitude test applied on the experimental group students were taken a basis to divide the students into three groups as the higher, middle and lower level scorers. According to the maximum variety sampling, one student from each level was chosen. So, six students from two experimental groups were interviewed personally. The qualitative data obtained at the end of the interviews were assessed and interpreted. The procedure applied to the groups is given in Table 2 below.

Table 2. Application Procedure

\begin{tabular}{|c|c|c|c|}
\hline Groups & $\begin{array}{l}\text { Before the } \\
\text { Application }\end{array}$ & $\begin{array}{c}\text { The } \\
\text { Application }\end{array}$ & $\begin{array}{c}\text { After the } \\
\text { Application }\end{array}$ \\
\hline Experimental & $\begin{array}{c}\text { Achievement } \\
\text { Test, Attitude } \\
\text { Questionnaire } \\
\text { (M1) }\end{array}$ & $\begin{array}{c}\text { Teaching } \\
\text { and } \\
\text { Application } \\
\text { of } \\
\text { Writing } \\
\text { Letter } \\
\text { Activity }\end{array}$ & $\begin{array}{c}\text { Achievement } \\
\text { Test, Attitude } \\
\text { Questionnaire, } \\
\text { Interview (M2) }\end{array}$ \\
\hline Control & $\begin{array}{c}\text { Achievement } \\
\text { Test, Attitude } \\
\text { Questionnaire } \\
\text { (M3) }\end{array}$ & $\begin{array}{c}\text { Regular } \\
\text { Teaching } \\
\text { and } \\
\text { Exercises }\end{array}$ & $\begin{array}{c}\text { Achievement } \\
\text { Test, Attitude } \\
\text { Questionnaire } \\
\text { (M4) }\end{array}$ \\
\hline
\end{tabular}

*M : Measurement

\subsection{Working Group}

The research performed on $11^{\text {th }}$ grade students of A High School located in a town in the Black Sea Region. Prior to the beginning of the study, a lot was drawn among the $9^{\text {th }}$, $10^{\text {th }}, 11^{\text {th }}$ and $12^{\text {th }}$ grade students studying in A high School and the 11th grade students were elected. Again a lot was drawn to divide the students into one control and two experimental groups. These groups were named as the Experimental Group 1 (EG1), Experimental Group 2 (EG2) and the Control Group 1 (CG1). 84 students in total participated in the research; EG1 consisted of 29 students (10 males, 19 females), EG2 consisted of 32 students (32 females) and the CG consisted of 23 students (23 males).

\subsection{Data Collection Tools}

This section gives information about the data collection 
tools utilized in this research.

\subsubsection{Simple Past Tense Achievement Test}

In the research, the achievement test prepared by the researcher for the "Simple Past Tense" was utilized. Test questions were elected from the question pool that contained 130 questions. 55 questions considered to be of the same quality were removed out based on the views of experts and 75 questions were used. In order to ensure construct validity and reliability of the activity, initially, it was performed with $26612^{\text {th }}$ graders who studied the same subject the previous year. Content validity is more important in achievement tests to ensure the validity of the test, and this can be achieved with expert opinions [27]. Expert opinions were received from nine English language teachers and four curriculum programmers to ensure the content validity of the test. The final 25 questions selected based on these views, can be stated to be valid. The results of the reliability and validity study performed with these 25 questions are presented in Table 3.

Table 3. Item Analysis Results of SPTAT

\begin{tabular}{|c|c|c|c|c|c|c|}
\hline & Number & d & $\mathrm{p}$ & $\begin{array}{l}\text { Cronbach } \\
\text { Alpha }\end{array}$ & $\begin{array}{c}\text { Item-total correlation } \\
\text { values }\end{array}$ & $\begin{array}{l}\text { Spearman Brown } \\
\text { split-half Test (r) }\end{array}$ \\
\hline 1 & S1 & 0.45 & 0.52 & & 0.47 & \\
\hline 2 & S4 & 0.38 & 0.40 & & 0.38 & \\
\hline 3 & S5 & 0.52 & 0.43 & & 0.50 & \\
\hline 4 & S7 & 0.36 & 0.44 & & 0.39 & \\
\hline 5 & S10 & 0.40 & 0.45 & & 0.45 & \\
\hline 6 & $\mathrm{~S} 13$ & 0.40 & 0.36 & & 0.41 & \\
\hline 7 & S16 & 0.32 & 0.45 & & 0.53 & \\
\hline 8 & S19 & 0.31 & 0.35 & & 0.63 & \\
\hline 9 & S24 & 0.39 & 0.51 & & 0.61 & \\
\hline 10 & S29 & 0.39 & 0.47 & & 0.41 & \\
\hline 11 & $\mathrm{~S} 30$ & 0.35 & 0.48 & & 0.54 & \\
\hline 12 & $\mathrm{~S} 32$ & 0.37 & 0.38 & & 0.38 & \\
\hline 13 & S33 & 0.32 & 0.40 & 0.81 & 0.53 & 0.89 \\
\hline 14 & S35 & 0.39 & 0.49 & & 0.55 & \\
\hline 15 & S36 & 0.31 & 0.44 & & 0.53 & \\
\hline 16 & S42 & 0.30 & 0.44 & & 0.50 & \\
\hline 17 & S44 & 0.35 & 0.39 & & 0.45 & \\
\hline 18 & S47 & 0.31 & 0.34 & & 0.51 & \\
\hline 19 & S48 & 0.31 & 0.39 & & 0.49 & \\
\hline 20 & S53 & 0.38 & 0.38 & & 0.52 & \\
\hline 21 & S54 & 0.31 & 0.39 & & 0.40 & \\
\hline 22 & S56 & 0.31 & 0.42 & & 0.44 & \\
\hline 23 & S60 & 0.38 & 0.45 & & 0.39 & \\
\hline 24 & S61 & 0.32 & 0.36 & & 0.40 & \\
\hline 25 & S70 & 0.32 & 0.38 & & 0.44 & \\
\hline
\end{tabular}


The average difficulty level of these 25 questions was found to be 0.54 . Considering this rate, it can be stated that; the difficulty levels of these items have a balanced distribution. The average distinctiveness of the test was found to be 0.36 , and it can be stated that; the items have a good level of distinctiveness. Total correlation of the elements in the test was found to be varying from 0.38 to 0.63 . The test items were divided into two halves as single and double, and the Spearman-Brown formula was used. The value obtained at the end of the analysis was 0.89 . The test can be stated to have a suitable level of distinctiveness as a result of the Cronbach Alpha and item-total correlation values. The test measures the characteristics accurately, and it can be regarded to be reliable. All these opinions can make us reach the conclusion that the test is suitable.

\subsubsection{Attitude to English Lesson Questionnaire}

The research made use of the attitude scale that consisted of 28 five Likert-type items developed by Erdem [28]. There were 14 positive and 14 negative statements in the Likert-type scale. The questions were in five Likert-type and the answers were given as (1) I totally disagree, (2) I do not agree, (3) I agree partially, (4) I agree, (5) I totally agree. The most negative statement was given 1 point, the most positive statement was given 5 points; the assessment was made by scoring from 1 to 5 . Whereas the high score obtained from the test revealed out a strong attitude towards the lesson, the low score revealed out a low attitude towards the lesson. Necessary actions were taken for validity and reliability. Basic Components were used for the construct validity of the scale, and the Cronbach Alpha analysis was made for its reliability. The Basic Components Analysis showed that the scale items were gathered under a single dimension. $61.21 \%$ of the scale variance was explained with the first component. The internal coherence coefficient was found to be 0.97 . In parallel with these data, it can be stated that the scale is valid and reliable [29]. The attitude reliability (Cronbach Alpha) coefficient for the English lesson was found as 0.89 in this research.

\subsubsection{Interview Questions}

As the research is a quantity based research mostly, the experts stated that the data obtained through the structured interview questions were more suitable. The interview questions consisted of structured questions. These structured interview questions prepared according to the opinions of five branch teachers and three curriculum programmers were directed to the students and the qualitative data were analysed. One of the most significant benefits of the utilization of the structured interview technique can be the fact that, it minimizes the difference among the interviewers where there are multiple interviewers [30].

\subsection{Data Analysis}

Considering the results of the Levene test it was found out that; the groups did not have a homogeneous variance.
Normality analysis was conducted to test whether the data obtained through the achievement test and the attitude test presented a normal distribution or not. The results of the KWS test showed that the distribution was not normal. In situations where there are no parametric assumptions, utilization of non-parametric tests is more suitable. Thus; non-parametric tests were utilized in the analysis of the data obtained through the achievement test and the attitude scale. The analyses regarding the results of the pre-tests applied on the groups are presented in Table 2, Table 3, Table 4 and Table 5 .

Table 4. Descriptive results of SPTAT Pre test

\begin{tabular}{cccc}
\hline Groups & $\mathrm{N}$ & $\mathrm{X}$ & $\mathrm{SS}$ \\
\hline EG1 & 29 & 59,72 & 16,70 \\
EG2 & 32 & 51,88 & 14,13 \\
CG & 23 & 50,96 & 18,89 \\
\hline
\end{tabular}

Table 4 shows the achievement test scores of the students in the control and experimental groups. The average score of the students was the lowest in the CG, then came the EG2 and the EG1 scored the highest. The Kruskal-Wallis analysis was made to test whether the difference among these scores was statistically significant or not. The results of the analysis are presented in Table 5 .

Table 5. Kruskal -Wallis Analysis Results of SPTAT Pre test

\begin{tabular}{cccccc}
\hline Groups & N & Mean Rank & sd & $\mathrm{X}^{2}$ & $\mathrm{p}$ \\
\hline EG1 & 29 & 50,28 & & & \\
EG2 & 32 & 38,91 & 2 & 4,586 & 0,101 \\
CG & 23 & 37,70 & & & \\
\hline
\end{tabular}

Table 5 shows that; there is no statistically significant difference among the score averages the students in the groups had in the achievement pre-test $\left(\mathrm{X}_{(2)}^{2}=4,586 ; \mathrm{p}>0,05\right)$. The background SPT knowledge of the students in the control and experimental groups can be considered to be similar prior to the application of the activity. The descriptive statistics of the scores the students received from the attitude pre-test are presented in Table 6 .

Table 6. Descriptive results of AELQ Pre test

\begin{tabular}{cccc}
\hline Groups & N & X & SS \\
\hline EG1 & 29 & 106,41 & 16,28 \\
EG2 & 32 & 107,81 & 15,93 \\
CG & 23 & 110,91 & 15,23 \\
\hline
\end{tabular}

Table 6 shows that; the students in EG1 had the lowest score average, then came EG2 and the CG had the highest scores. The Kruskal -Wallis analysis was made to test whether the difference among the groups was statistically significant or not. The results of the analysis are presented in Table 7. 
Table 7. Kruskal -Wallis Analysis Results of AELQ Pre test

\begin{tabular}{cccccc}
\hline Groups & N & Mean Ranks & sd & $\mathrm{X}^{2}$ & $\mathrm{p}$ \\
\hline EG1 & 29 & 37,57 & & & \\
EG2 & 32 & 41,67 & 2 & 0,969 & 0,616 \\
CG & 23 & 43,96 & & & \\
\hline
\end{tabular}

Table 7 shows that; there is no statistically significant difference among the average scores the students in the groups had in the attitude pre-test $\left(\mathrm{X}^{2}{ }_{(2)}=0,969 ; \mathrm{p}>0,05\right)$. According to this result, the students in the experimental and control groups can be stated to have a similar attitude towards the WTL activity. The pre-tests also show that; all the groups are similar in terms of the levels of academic success and attitude towards the lesson.

\section{Findings and Comments}

This section contains the data obtained from the SPT Achievement Test, Attitude Survey and the data obtained from the interviews made with the students, the findings organized according to the research hypotheses and the interpretation.

\subsection{Findings and Comments about the First Hypothesis}

The SPT Achievement Test prepared by the researcher was applied in order to test the hypothesis "Considering the pre-test and post-test scores received by the students in the control and experimental groups, there is a statistically significant difference in favor of the experimental groups." The data obtained about this hypothesis are presented in Table 8 .

Table 8 shows that; considering the achievement pre-test and post-test scores received by the students in the groups, there is a statistically significant difference in favor of the post achievement test (EG1: $Z=4,711 ; p<0,05$. $E G 2$ : $Z=4,948 ; p<0,05 . C G: Z=3,839 ; p<0,05)$. The activities applied to the control, and experimental groups can be stated to have a positive effect on the success of the students in the Simple Past Tense. The data obtained showed the correctness of the first hypothesis in the research.

\subsection{Findings and Comments about the Second Hypothesis}

The SPT Achievement Test prepared by the researcher was applied in order to test the hypothesis "Considering the pre-test and post-test scores received by the students in the control and experimental groups, there is a statistically significant difference in favor of the experimental groups." The data obtained about this hypothesis are presented in Tables 9 and 10 .

Table 9.. Descriptive results of SPTAT Post test

\begin{tabular}{cccc}
\hline Groups & N & X & SS \\
\hline EG1 & 29 & 93,66 & 9,35 \\
EG2 & 32 & 89,56 & 11,41 \\
CG & 23 & 65,22 & 12,79 \\
\hline
\end{tabular}

Table 9 shows that; the average post achievement test scores received by the students in the experimental group are higher than the average scores received by the students in the CG. The Kruskal -Wallis analysis was made to test whether the difference between the scores was statistically significant or not and the results of the analysis are presented in Table 10. The correctness of the second hypothesis was proven.

Table 10. Kruskal -Wallis Analysis Results of SPTAT Post test

\begin{tabular}{ccccccc}
\hline Groups & $\mathrm{N}$ & Mean Ranks & $\mathrm{sd}$ & $\mathrm{X}^{2}$ & $\mathrm{p}$ & Difference \\
\hline EG1 & 29 & 57,24 & 2 & 40,333 & 0,000 & EG1-CG \\
EG2 & 32 & 48,16 & & & & EG2-CG \\
CG & 23 & 16,04 & & & & \\
\hline
\end{tabular}

Table 10 shows that; considering the average scores received by the students in the post achievement test, there is a statistically significant difference among the groups $\left(\mathrm{X}_{(2)}^{2}=40,333 ; \mathrm{p}<0,05\right)$. The Mann-Whitney $U$ analysis was made in groups of two to understand this difference. There was a statistically significant difference between EG1 and $\mathrm{CG}$ and EG2 and CG $(\mathrm{p}<0,05)$. According to the results of the Mann-Whitney U analysis, the students in EG1 and EG2 were more successful than the students in the CG. It can be concluded from the results given in Table 9 and 10. that; the WTL Activity had a positive effect on the students' success in the SPT. The correctness of the second hypothesis was proven.

Table 8. Wilcoxon signed-ranks Test Results of pre and post-test scores of SPTAT

\begin{tabular}{|c|c|c|c|c|c|c|}
\hline Groups & Last Measurement & $\mathrm{N}$ & Mean Ranks & Sum of Ranks & $Z$ & $\mathrm{p}$ \\
\hline \multirow{4}{*}{ EG1 } & Negative Ranks & 0 & 0,00 & 0,00 & 4,711 & 0,00 \\
\hline & Positive Ranks & 29 & 15,00 & 435,00 & & \\
\hline & Ties & 0 & & & & \\
\hline & Total & 29 & & & & \\
\hline \multirow{4}{*}{ EG2 } & Negative Ranks & 0 & 0,00 & 0,00 & 4,948 & 0,00 \\
\hline & Positive Ranks & 32 & 16,50 & 528,00 & & \\
\hline & Ties & 0 & & & & \\
\hline & Total & 32 & & & & \\
\hline \multirow{4}{*}{$\mathrm{CG}$} & Negative Ranks & 1 & 2,50 & 2,50 & 3,839 & 0,00 \\
\hline & Positive Ranks & 19 & 10,92 & 207,50 & & \\
\hline & Ties & 3 & & & & \\
\hline & Total & 23 & & & & \\
\hline
\end{tabular}


Table 11. Wilcoxon signed-ranks Test Results of pre and post-test scores of AELQ

\begin{tabular}{|c|c|c|c|c|c|c|}
\hline Groups & Last Measurement & $\mathrm{N}$ & Mean Rank & Sum of Ranks & Z & $P$ \\
\hline & Negative Ranks & 8 & 11,44 & 91,50 & 2,540 & 0,011 \\
\hline \multirow[t]{4}{*}{ EG1 } & Positive Ranks & 20 & 15,73 & 314,50 & & \\
\hline & Ties & 1 & & & & \\
\hline & Total & 29 & & & & \\
\hline & Negative Ranks & 12 & 13,79 & 165,50 & 1,379 & 0,168 \\
\hline \multirow[t]{4}{*}{ EG2 } & Positive Ranks & 18 & 16,64 & 299,50 & & \\
\hline & Ties & 2 & & & & \\
\hline & Total & 32 & & & & \\
\hline & Negative Ranks & 16 & 11,90 & 178,50 & $-1,689$ & 0,091 \\
\hline \multirow[t]{3}{*}{$\mathrm{CG}$} & Positive Ranks & 7 & 10,64 & 74,50 & & \\
\hline & Ties & 0 & & & & \\
\hline & Total & 23 & & & & \\
\hline
\end{tabular}

\subsection{Findings and Comments about the Third Hypothesis}

The Attitude Scale was applied in order to test the hypothesis "Considering the lesson attitude pre-test and post-test scores received by the students in the control and experimental groups, there is a statistically significant difference in favor of the experimental groups." The data obtained about this hypothesis are presented in Table 11.

Table 11 shows that; considering the average scores received by the students in EG1 in the attitude pre and post-tests, there is a statistically significant difference in favour of the post attitude test (EG1: $Z=2,540 ; p<0,05$ ). It can be concluded that; the WTL had a positive effect on the EG1 students' attitude towards the Simple Past Tense. There was no statistically significant difference between the scores the EG2 students received from the attitude pre and post-tests (EG2: $Z=1,379 ; p>0,05)$. It can be concluded that; the method used had a positive effect on the students' attitude towards the lesson, but this effect was not statistically significant. So; the correctness of the third hypothesis was proven for EG1 but not for EG2.

\subsection{Findings and Comments about the Fourth Hypothesis}

The Attitude Scale was applied in order to test the hypothesis "Considering the lesson attitude post test scores received by the students in the control and experimental groups, there is a statistically significant difference in favour of the experimental groups." The data obtained about this hypothesis are presented in Tables 12 and 13

Table 12. Descriptive results of AELQ Post test

\begin{tabular}{cccc}
\hline Groups & N & X & SS \\
\hline EG1 & 29 & 118,55 & 14,24 \\
EG2 & 32 & 112,38 & 13,97 \\
CG & 23 & 102,61 & 13,87 \\
\hline
\end{tabular}

Table 12 shows that; considering the average scores received by the students in the post attitude test; the students in EG1 scored the highest, then came the EG2 and the CG. The Kruskal -Wallis analysis was made to test whether the difference between the scores was statistically significant or not and the results of the analysis are presented in Table 13.

Table 13. Kruskal -Wallis Analysis Results of AELQ Post test

\begin{tabular}{ccccccc}
\hline Grou & $\mathrm{N}$ & Mean Ranks & $\mathrm{s}$ & $\mathrm{X}^{2}$ & $\mathrm{p}$ & Difference \\
\hline EG1 & 29 & 53,47 & 2 & 13,788 & 0,001 & DG1-KG \\
Grou & & & & & & \\
EG2 & 32 & 42,84 & & & & DG2-KG \\
Grou & & & & & & \\
CG & 23 & 28,20 & & & & \\
Grou & 23 & & & & & \\
\hline
\end{tabular}

Table 13 shows that; considering the average scores received by the students in the post attitude test; there is a significant difference among the scores $\left(\mathrm{X}_{(2)}^{2}=13,788\right.$; $\mathrm{p}<0,05)$. The Mann-Whitney $\mathrm{U}$ analysis was made in groups of two to understand this difference. There was a statistically significant difference between EG1 and CG; and between EG2 and CG $(p<0,05)$. According to the results of the $U$ analysis, the students in EG1 and EG2 were had a higher attitude than the students in the CG. The correctness of the fourth hypothesis was proven.

\subsection{Findings and Comments about the Fifth Hypothesis}

Interview questions were prepared based on the opinions of experts in order to test the correctness of the hypothesis "the students in the experimental group have positive opinions about the activities applied on them" and these questions were directed to the students. The first student interviewed was called as $\mathrm{S} 1$ (high), the second student as S2 (medium), the third student as S3 (low), the fourth student as S4 (high), the fifth student as S5 (medium) and the sixth student as S6 (low).

Three students elected according to their achievement test scores were asked five questions. A few of these questions and answers were given as an example. The analysis of the replies given to the question "How (whether positive or 
negative) did the letter writing activity affect your learning of the Simple Past Tense (SPT)?" showed that all the three students were affected positively. For example (S3) said: "We learned the SPT then we learned how to write the letter, and I think I wrote the letter better. Certainly it had a positive effect on writing letters after learning the SPT." The second question directed to the students was; "How did you use the things you have learned in the lesson when writing the letter?" (S2) said: "... If you do not have the knowledge, if you do not know anything, then you cannot do, but when you learn, you make a contribution, and you believe you can do better. This was positive for us." Considering these answers, it can be stated that; the letter writing activity helped the students to express their knowledge by integrating the things they have learned in the letter writing activity with their background knowledge. The third question was; "How did the letter writing activity affect you learning of the lesson subjects? Do you think you could have learned the same even if we had not applied this activity?" (S1) answered the question as the following: "After writing the letter, I realized that the knowledge was consolidated. It was not that I only read and wrote a letter in daily life. After writing, I read it to a friend. I can say that my perspective got widened while reading. When you write something, it is just a simple activity of writing. However, if you thoroughly understand what you have written, then it remains in your mind forever. This is what I think." Furthermore; the answers given by the students to the questions regarding the effect of the letter activity on the academic success were analysed. It was determined that the students found the activity had a positive and systematic effect on consolidating the knowledge, enabled understanding the concept, allowed better learning through explanation, and would be suitable to use the activity in oral lessons. It can be concluded from these answers that; the activity had a positive effect on the academic success of the students, and the students had a favourable opinion about the activity.

Three students elected according to their attitude survey scores were asked five questions. A few of these questions and answers were given as an example. The first question was; "How much important is the English lesson for you?". (S4) answered: "I think the English lesson is essential to have friends from different countries, to learn about their perspectives to add them to our own in order to be able to view the world through a wider perspective." The second question was; "What if the English lesson was not compulsory but elective?" (S5) answered: "It would be better if it were an elective lesson, then we would be able to arrange the course hours according to ourselves..." The fifth and the final question was: "What do you think about the weekly class hours of the English lesson?" (S6) said: "Insufficient, because the subjects are too many. Will we use the class hour for vocabulary, speaking or listening? Why do I think that it is not sufficient because I have always tried to improve my English by looking at the subtitles of the movies or by speaking. I think I can be successful in this way, not only by being bound to the subject. However, in just two hours how can you do all these? So, I think the class hours are insufficient". It can be concluded from the analysis of these answers that; the students in the experimental group had a positive attitude towards the lesson, and the activity contributed to this positive effect. These results prove the correctness of the third hypothesis.

\section{Results and Discussion}

The results of the SPTAT and the interview questions intended for the testing of the academic success showed that; WTL was influential in enhancing the academic success. The results concerning the academic success of the students reveal out a parallelism with the studies conducted by making use of the WTL activity (31-50]. Considering the values obtained at the end of the research, it was found that; the students who were taught the SPT through the letter writing activity, which is one of the WTL activities, became more successful than the students who were taught through the traditional teaching method. Utilization of the WTL activities in the English lesson enhances the academic success of the students. Attitude survey was applied to the students and interview questions were asked in order to obtain the values concerning the attitudes towards the lesson. When the scores received from the attitude survey prior to the activity were analysed, it was found that; there was no significant difference among the groups, on the other hand, after the activity, there emerged a statistically significant difference in favour of the experimental groups. The data obtained through the interviews also support this result (S4, S5, S6). However; though there was an increase in the attitude scores of the students in EG2, this does not present a statistical significance. As the attitude does not change depending on the variable defined, we can think that factors are affecting the attitudes [51]. It can be stated that; there are factors other than the teaching method that are affecting the attitudes, and the result came out of those. There might be several factors that influence the attitudes of the students towards the English lesson $[52,53]$. There was a statistical significance in the attitude of one of the two experimental groups, and the other experimental group showed an increase though there was no statistical difference. So, we can conclude that; WTL activities affect the attitude positively. In literature, there are studies which report that the other factors influencing the relationship between success and attitude were not explained exactly and that, there is a need for such studies that intend to explain that [54]. Utilization of the WTL method in the classroom may not be sufficient on its own. The effect might gain statistical significance if the activities are applied in consideration with the other factors.

On the other hand; the significant difference observed in the attitudes of EG1 students in this research can mean that all these variables came together to create this effect. This result shows a similarity with the results gained in the 
previous studies [55-63]. It was observed that; EG1 had higher pre scores and better attitudes whereas EG2 showed an improvement but the difference was not statistically significant. It can be concluded that; when the educators utilize this activity in consideration with the other factors affecting the attitude, this might help the students to develop a positive attitude towards the English lesson.

Furthermore; in the answers given by the students about the effect of the letter writing activity on their attitudes towards the lesson revealed that the students regarded the English lesson as a valuable lesson, thought the English language was as common as their mother tongue, and they would take it even if it were an elective. The students stated that they liked the activity, it was good to lecture the others, and they felt wise to do so. The students expressed positive statements about the lesson. Considering these statements, it can be concluded that; this activity helped the students to develop a positive attitude towards the lesson. This result also conforms to the results of the other studies in literature [64-68].

The "letter" writing activity which is one of the Writing To Learn activities, is observed to have a positive effect on the enhancement of the students' academic success in the English lesson and to improve their attitudes towards the lesson. It is thought that utilization of this activity in the English lesson will make a contribution to the students.

\section{REFERENCES}

[1] Castello, M., Mateos, M., Castells, N., Inesta, A., Cuevas, I. and Sole, I. (2012). Academic Writing Practices in Spanish Universities. Electronic Journal of Research in Educational Psychology,10(2), 569-590.

[2] Jani, J. S. and Mellinger, M. S. (2015). Beyond "Writing to Learn": Factors Influencing Students' Writing Outcomes. Journal of Social Work Education, 51(1), 136-152.

[3] Gallavan, N. P., Bowles, F. A. and Young, C. T. (2007). Learning to Write and Writing to Learn: Insights from Teacher Candidates. Action in Teacher Education, 29(2), 61-69.

[4] Günel, M. Atila, M. E. ve Büyükkasap, E. (2009). The Impact of Using Multi Modal Representations within Writing to Learn Activities on Learning Electricity Unit at 6th Grade. Ilkögrretim Online, 8(1), 183-199.

[5] Günel, M., Uzoğlu, M. ve Büyükkasap, E. (2009). Öğrenme Amaçlı Yazma Aktivitelerinin Kullanımının ilköğretim Seviyesinde Kuvvet Konusunu Öğrenmeye Etkisi. Gazi Üniversitesi Gazi Eğitim Fakültesi Dergisi, 29(1), 379-399.

[6] İncirci, A. and Parmaksız, R. Ş. (2016). The Effect of Applying The "Writing Letter" To Learn in English Class on the Metacognition Level of Students. XVIII ${ }^{\text {th }}$ AMSE-AMCE-WAER International Congress: Eskişehir, Turkey,

[7] McDermott, M. (2010). More than Writing-to-Learn. Science Teacher, 77(1), 32-36.
[8] Balgopal, M. M., Wallace, A. M. and Dahlberg, S. (2012). Writing to Learn Ecology: A Study of Three Populations of College Students. Environmental Education Research, 18(1), $67-90$.

[9] Dukewich, K. R. and Vossen, D. P. (2015). Toward Accuracy, Depth and Insight: How Reflective Writing Assignments Can Be Used to Address Multiple Learning Objectives in Small and Large Courses. Collected Essays on Learning and Teaching, 8, 97-110.

[10] Gillespie, A., Graham, S., Kiuhara, S. and Hebert, M. (2014). High School Teachers Use of Writing to Support Students' Learning: A National Survey. Reading and Writing: An Interdisciplinary Journal, 27(6), 1043-1072.

[11] Hohenshell, L. M. and Hand, B. (2006). Writing-to-Learn Strategies in Secondary School Cell Biology: A Mixed Method Study. International Journal of Science Education, 28(2-3), 261-289.

[12] Tomas, L. and Ritchie, S. M. (2015). The Challenge of Evaluating Students'Scientific Literacy in a Writing-to-Learn Context. Research in Science Education, 45(1), 41-58.

[13] Shultz, G. V. and Gere, A. R. (2015). Writing-to-Learn the Nature of Science in the Context of the Lewis Dot Structure Model. Journal of Chemical Education, 92(8), 1325-1329.

[14] Jani, J. S. and Mellinger, M. S. (2015). Beyond "Writing to Learn": Factors Influencing Students' Writing Outcomes. Journal of Social Work Education, 51(1), 136-152.

[15] Jordon, S. (2014). Writing to Learn the Reformation: Or, Who Was Ulrich Zwingli and Why Should I Care? Teaching Theology \& Religion, 17(1), 50-60.

[16] Comer, D. K., Clark, C. R. and Canelas, D. A. (2014). Writing to Learn and Learning to Write across the Disciplines: Peer-to-Peer Writing in Introductory-Level MOOCs. International Review of Research in Open and Distance Learning, 15(5), 26-82.

[17] Whitehead, D. and Murphy, F. (2014). "Mind Your Language": High School Students Write Laboratory Reports. Journal of Adolescent \& Adult Literacy, 57(6), $492-502$

[18] Bifuh-Ambe, E. (2013). Developing Successful Writing Teachers: Outcomes of Professional Development Exploring Teachers' Perceptions of Themselves as Writers and Writing Teachers and Their Students' Attitudes and Abilities to Write across the Curriculum. English Teaching: Practice and Critique, 12(3), 137-156.

[19] McDermott, M. A. ve Hand, B. (2013). The Impact of Embedding Multiple Modes of Representation within Writing Tasks on High School Students' Chemistry Understanding. Instructional Science: An International Journal of the Learning Sciences, 41(1), 217-246.

[20] Fernandes, A. S. C. (2012). Writing to Learn Writing Skills--A Case Study. European Journal of Engineering Education, 37(2), 179-192.

[21] Jarman, R. and Mc Clune, B. (2012). Student-Authored Podcasts: A Valuable "Writing-to-Learn" Task for Promoting Science Learning and Literacy. School Science Review, 94(346), 120-128.

[22] Northrup, C. G. (2012). Writing to Learn Statistics in an 
Advanced Placement Statistics Course. ProQuest LLC, Ph.D. Dissertation, The University of North Carolina at Charlotte.

[23] İncirci, A. (2016). The effect of applying the 'writing letter' to learn in English class on the academic achievement, attitude to lesson and metacognition level. Msc Thesis. Bulent Ecevit University: Zonguldak, Turkey.

[24] Temizöz, H. (2008). Yabancı Dil Öğretiminde Dilbilgisi Çeviri Yöntemi Ve İletişimci Yaklaşım Uygulamalarının, Öğrencilerin Öğrenme Becerisi Üzerindeki Etkisi. Yüksek Lisans Tezi. İnönü Üniversitesi, Malatya.

[25] Stout, R. P. (2010). "Hello, I'm Carbon.": Writing about Elements and Compounds. Journal of Chemical Education, 87(11), 1163-1165.

[26] Yıldırım, A. and Şimşek, H. (2004). Sosyal Bilimlerde Nitel Araştırma Yöntemleri. Ankara: Seçkin.

[27] Büyüköztürk, Ş. (2014). Sosyal Bilimler için Veri Analizi El Kitabı. Ankara: Pegem A Yayıncılı.

[28] Erdem, D. (2007). İngilizce Dersine Yönelik Bir Tutum Ölçeği Geliştirme Çalışması. Eurasian Journal of Educational Research, 48, 45-54.

[29] Erdem, D. (2007). İngilizce Dersine Yönelik Bir Tutum Ölçeği Geliştirme Çalışması. Eurasian Journal of Educational Research,48, 45-54.

[30] Patton, M. (1990). Qualitative evaluation and research methods (pp. 169-186).Beverly Hills, CA: Sage.

[31] Akçay, H., Hand, B. and Norton-Meier, L. (2010). Creative Writing and Promoting Understanding in Science: Alternative Ways to Interest Students in Writing about Science. School Science Review, 92(339), 49-53.

[32] Balgopal, M. M., Wallace, A. M. and Dahlberg, S. (2012). Writing to Learn Ecology: A Study of Three Populations of College Students. Environmental Education Research, 18(1), 67-90.

[33] Biber, B. (2012). Fen ve Teknoloji Öğretmenlerinin Yazmaya Dair Algıları ve Öğrenme Amaçlı Yazma Aktivitelerini Uygulama Düzeyleri. Yüksek Lisans Tezi. Atatürk Üniversitesi, Eğitim Bilimleri Enstitüsü, Erzurum.

[34] Bozat, Ö. (2014). 5. Sınıf Yaşamımızdaki Elektrik Ünitesinde Öğrenme Amaçlı Yazma Etkinliklerinden Mektubun Başarıya Etkisi. Yükssek Lisans Tezi. Atatürk Üniversitesi.

[35] Castello, M., Mateos, M., Castells, N., Inesta, A., Cuevas, I. and Sole, I. (2012). Academic Writing Practices in Spanish Universities. Electronic Journal of Research in Educational Psychology,10(2), 569-590.

[36] Comer, D. K., Clark, C. R. and Canelas, D. A. (2014). Writing to Learn and Learning to Write across the Disciplines: Peer-to-Peer Writing in Introductory-Level MOOCs. International Review of Research in Open and Distance Learning, 15(5), 26-82.

[37] Duymaz, N. (2011). Hücre Konusunun Öğrenilmesinde Öğrenme Amaçlı Yazma Etkinliklerinin Kullanımı ve Analoji Üretme. Yüksek Lisans Tezi. Gazi Üniversitesi, Ankara.

[38] Gute, D. and Gute, G. (2008). Flow Writing in the Liberal Arts Core and across the Disciplines: A Vehicle for Confronting and Transforming Academic Disengagement.
Journal of General Education, 57(4), 191-222.

[39] Günel, M., Atila, M. E. and Büyükkasap, E. (2009). The Impact of Using Multi Modal Representations within Writing to Learn Activities on Learning Electricity Unit at 6th Grade. İlköğretim Online, 8(1), 183-199.

[40] Jani, J. S. and Mellinger, M. S. (2015). Beyond "Writing to Learn": Factors Influencing Students' Writing Outcomes. Journal of Social Work Education, 51(1), 136-152.

[41] Jarman, R. and Mc Clune, B. (2012). Student-Authored Podcasts: A Valuable "Writing-to-Learn" Task for Promoting Science Learning and Literacy. School Science Review, 94(346), 120-128.

[42] Jordon, S. (2014). Writing to Learn the Reformation: Or, Who Was Ulrich Zwingli and Why Should I Care? Teaching Theology \& Religion, 17(1), 50-60.

[43] Knipper, K. J. and Duggan, T. J. (2006). Writing to Learn across the Curriculum: Tools for Comprehension in Content Area Classes. Reading Teacher, 59(5), 462-470.

[44] McDermott, M. A. and Hand, B. (2013). The Impact of Embedding Multiple Modes of Representation within Writing Tasks on High School Students' Chemistry Understanding. Instructional Science: An International Journal of the Learning Sciences, 41(1), 217-246.

[45] Öztürk, S. (2014). Lise-1 Düzeyindeki Öğrencilerin Modsal Betimlemeleri Tanıyıp Öğrenme Amaçlı Yazmada Kullanmalarının Fizik Dersi Dalgalar Ünitesindeki Akademik Başarıya Etkisi. Yüksek Lisans Tezi, Atatürk Üniversitesi, Erzurum.

[46] Rivard, L. P. and Straw, S. B. (2000). The effect of talk and writing on learning science: An exploratory study. Science Education, 84(5), 566-593.

[47] Shultz, G. V. and Gere, A. R. (2015). Writing-to-Learn the Nature of Science in the Context of the Lewis Dot Structure Model. Journal of Chemical Education, 92(8), 1325-1329.

[48] Tomas, L. and Ritchie, S. M. (2015). The Challenge of Evaluating Students' Scientific Literacy in a Writing-to-Learn Context. Research in Science Education, 45(1), 41-58.

[49] Van De Weghe, R. (2005). What Are the Effects of Writing-to-Learn Programs? English Journal, 95(2), 97.

[50] Whitehead, D. and Murphy, F. (2014). "Mind Your Language": High School Students Write Laboratory Reports. Journal of Adolescent \& Adult Literacy, 57(6), 492-502.

[51] Githua, B. N. and Mwangi, J. G. (2003). Students' mathematics self-concept and motivation to learn mathematics: relationship and gender differences among Kenya's secondary-school students in Nairobi and Rift Valley provinces. International Journal of Educational Development, 23(5), 487-499.

[52] Yurdabakan, G. (2010). İletişimsel Yaklaşımla "If Clause'’Konusunun Öğretiminin, 11. Sınıf Öğrencilerinin İngilizce Dersine Karşı Tutum ve Başarısına Etkisi. Yüksek lisans tezi, Yeditepe Üniversitesi, İstanbul.

[53] Varmış Kılıç, Z. (2011). İngilizce Derslerinde Kullanılan Özgün Materyallerin 12. Sinıf Öğrencilerinin Tutum ve Güdülenmeleri Üzerindeki Etkisi. Yüksek lisans tezi. Akdeniz Üniversitesi, Antalya. 
[54] Yücel, Z. and Koç, M. (2011). İlköğretim öğrencilerinin matematik dersine karşı tutumlarının başarı düzeylerini yordama gücü ile cinsiyet arasındaki ilişki. İlköğretim Online, 10(1), 133-143.

[55] Bifuh-Ambe, E. (2013). Developing Successful Writing Teachers: Outcomes of Professional Development Exploring Teachers'Perceptions of Themselves as Writers and Writing Teachers and Their Students' Attitudes and Abilities to Write across the Curriculum. English Teaching: Practice and Critique, 12(3), 137-156.

[56] Comer, D. K., Clark, C. R. and Canelas, D. A. (2014). Writing to Learn and Learning to Write across the Disciplines: Peer-to-Peer Writing in Introductory-Level MOOCs. International Review of Research in Open and Distance Learning, 15(5), 26-82.

[57] Duymaz, N. (2011). Hücre Konusunun Öğrenilmesinde Öğrenme Amaçlı Yazma Etkinliklerinin Kullanımı ve Analoji Üretme. Yüksek Lisans Tezi. Gazi Üniversitesi, Ankara.

[58] Gute, D. and Gute, G. (2008). Flow Writing in the Liberal Arts Core and across the Disciplines: A Vehicle for Confronting and Transforming Academic Disengagement. Journal of General Education, 57(4), 191-222.

[59] Jarman, R. and Mc Clune, B. (2012). Student-Authored Podcasts: A Valuable "Writing-to-Learn" Task for Promoting Science Learning and Literacy. School Science Review, 94(346), 120-128.

[60] Jordon, S. (2014). Writing to Learn the Reformation: Or, Who Was Ulrich Zwingli and Why Should I Care? Teaching Theology \& Religion, 17(1), 50-60.

[61] Öztürk, S. (2014). Lise-1 Düzeyindeki Öğrencilerin Modsal
Betimlemeleri Tanıyıp Öğrenme Amaçlı Yazmada Kullanmalarının Fizik Dersi Dalgalar Ünitesindeki Akademik Başarıya Etkisi. Yüksek Lisans Tezi, Atatürk Üniversitesi, Erzurum.

[62] Stout, R. P. (2010). "Hello, I'm Carbon.": Writing about Elements and Compounds. Journal of Chemical Education, 87(11), 1163-1165.

[63] Whitehead, D. and Murphy, F. (2014). "Mind Your Language": High School Students Write Laboratory Reports. Journal of Adolescent \& Adult Literacy, 57(6), 492-502.

[64] Bifuh-Ambe, E. (2013). Developing Successful Writing Teachers: Outcomes of Professional Development Exploring Teachers' Perceptions of Themselves as Writers and Writing Teachers and Their Students' Attitudes and Abilities to Write across the Curriculum. English Teaching: Practice and Critique, 12(3), 137-156.

[65] Gute, D. and Gute, G. (2008). Flow Writing in the Liberal Arts Core and across the Disciplines: A Vehicle for Confronting and Transforming Academic Disengagement. Journal of General Education, 57(4), 191-222.

[66] Jarman, R. and Mc Clune, B. (2012). Student-Authored Podcasts: A Valuable "Writing-to-Learn" Task for Promoting Science Learning and Literacy. School Science Review, 94(346), 120-128.

[67] Stout, R. P. (2010). "Hello, I'm Carbon.": Writing about Elements and Compounds. Journal of Chemical Education, 87(11), 1163-1165.

[68] Whitehead, D. and Murphy, F. (2014). "Mind Your Language": High School Students Write Laboratory Reports. Journal of Adolescent \& Adult Literacy, 57(6), 492-502. 